Group I : control dict : cereals + soyabcan meal.

Group 2 : replacement of 50 p. Ioo soyabean meal by 4 p. Ioo untreated "keratin ".

Group 3 : replacement of 50 p. Joo soyabean meal by 4 p. 100 ultraground "keratin $n$.

For the cxperiments on "gelatin", only $z$ treatments were applied, i.e. 2 groups of 28 Large White pigs (I 4 castrated males, I 4 females) for the lot trials between 30 and $100 \mathrm{~kg}$ live weight and 2 groups of 4 growing male pigs for the digestibility study. The diets used were the following :

Group I : Control diet : cereals + soyabean meal.

Group 2 : Replacement of 50 p. Ioo soyabean meal by 4 p. Ioo gelatin.

For the lot trials, the pigs were kept in collective pens including 7 animals of the same sex fed according to the following feeding schedule : a $I_{7}$ p. roo protein diet during the growing period (30-6o kg live weight) and a $15 \mathrm{p}$. Ioo protein diet during the finishing period $(60-100 \mathrm{~kg}$ live weight).

The pigs used in the digestibility study received only the arowing diet " (paired feeding) and were subjected to a collecting period of $\mathrm{io}$ days.

With diets relatively rich in crude protein, replacement of half of the sovabean meal by + p. Ioo horn or gelatin meal did not bring about any marked lowering of the animals' performances.

Although pig skin meal has a well balanced amino acid composition for the pig, its digestibility is low (about $60 \mathrm{p}$. IOo) and definitely lower than that of soyabean protein. Ultragrinding did not improve digestibility and retention of these proteins.

Conversely, in the case of gelatin digestibility was high, but its supplementation ralue was low because of severe amino acid imbalances.

The fact that under our experimental conditions the influence of partial replacement of sovabean meal by 4 p. I oo horn meal or gelatin meal was almost non existent was probably due to the low performances recorded and to the relatively high protein level of the diets masking the amino acid imbalances of the latter.

\title{
Rapeseed meal for the growing pig. Preliminary results of a detoxification process in silage
}

\author{
L.-P. BORGIDA, G. VIROBEN \\ Laboratoire de Technologie des Aliments des Animaux, I. N. R. A., C. N. R. Z., \\ r8350 Jouy en Josas
}

Rapeseed meal, despite the high quality of its proteins, is of little use in pig feeds, because of its unpalatability and toxicity even at low levels.

The undesirable substances, i.e. vinylthioxazoliclone (VTO) and isothiocyanates (ITC) can be conomically eliminated by fermentation. Mixing of ear corn with husks (5o p. Ioo D.M.) and rapeseed meal (2:I D.M. basis) leads to a strong lactic fermentation with a limited protein and aminoacid degradation ( $2 \mathrm{p}$. I oo of the nitrogen content as ammonia) a total ITC and high VTO elimination.

Fed to $55 \mathrm{~kg}$ pigs, this silage rich in crude fiber was ingested at the same TMI level as an isonitrogen isocellulose mixture of corn silage, soyabean meal and straw provided semi ad libitum. Growth rate $(500 \mathrm{~g} / \mathrm{d})$ and thyroid weight measurements showed no ill effect of a $\mathrm{I} 6 \mathrm{p}$. Ioo (DMl basis) rapeseed meal level in the ration of growing-finishing pigs. 